\title{
Impact of a silver layer on the membrane of tap water filters on the microbiological quality of filtered water Ralf-Peter Vonberg*1, Dorit Sohr ${ }^{2}$, Juliane Bruderek ${ }^{1}$ and Petra Gastmeier ${ }^{1,2}$
}

\author{
Address: ${ }^{1}$ Institute for Medical Microbiology and Hospital Epidemiology, Medical School Hannover, Germany and ${ }^{2}$ Institute for Hygiene and \\ Environmental Medicine, Charité - University Medicine Berlin, Germany \\ Email: Ralf-Peter Vonberg* - Vonberg.Ralf@MH-Hannover.DE; Dorit Sohr - dorit.sohr@charite.de; Juliane Bruderek - Bruderek.Juliane@mh- \\ hannover.DE; Petra Gastmeier - petra.gastmeier@charite.de \\ * Corresponding author
}

Published: 8 October 2008

BMC Infectious Diseases 2008, 8:133 doi:10.1186/147/-2334-8-133
Received: 6 June 2008

Accepted: 8 October 2008

This article is available from: http://www.biomedcentral.com/I47I-2334/8//33

(c) 2008 Vonberg et al; licensee BioMed Central Ltd.

This is an Open Access article distributed under the terms of the Creative Commons Attribution License (http://creativecommons.org/licenses/by/2.0), which permits unrestricted use, distribution, and reproduction in any medium, provided the original work is properly cited.

\begin{abstract}
Background: Bacteria in the hospital's drinking water system represent a risk for the acquisition of a nosocomial infection in the severely immunocompromised host. Terminal tap water filters may be used to prevent nosocomial Legionnaires' disease. We present data from water samples using an improved kind of tap water filters.
\end{abstract}

Methods: In a blinded study on an intermediate care unit of the thoracic surgery department, a modified type of the Germlyser water filter (Aqua-Free Membrane Technology) with a newlyintroduced silver layer on the filtration membrane was compared to its preceding type without such a layer on 15 water outlets. We determined growth of Legionella, other pathogenic bacteria, and the total heterotrophic plate count in unfiltered water and filtered water samples after filter usage intervals of I through 4 weeks.

Results: A total of 299 water samples were tested. Twenty-nine of the 60 unfiltered water samples contained Legionella of various serogroups (baseline value). In contrast, all samples filtered by the original water filter and all but one of the water samples filtered by the modified filter type remained Legionella-free. No other pathogenic bacteria were detected in any filtered sample. The total plate count in water samples increased during use of both kinds of filters over time. However, for the first 7 days of use, there were significantly fewer water samples containing $>100$ CFU per $\mathrm{mL}$ when using the new filter device compared with the older filters or taps with no filter. No advantage was seen thereafter.

Conclusion: The use of this type of terminal water filter is an appropriate method to protect immunocompromised patients from water-borne pathogens such as Legionella.

\section{Background}

Legionella spp. are commonly detected in hospital water supply systems $[1,2]$. Especially in the severely immunocompromised host, such as patients after bone marrow or solid organ transplantation, these pathogens are wellknow causative agents of life-threatening nosocomial infections [3-5]. The minimal number of Legionella needed to actually cause disease remains unknown. Infection in susceptible individuals may occur at concentrations $<1$ colony forming unit (CFU) per $\mathrm{mL}$ [6]. That is why the use of pathogen-free water for high risk patient care is recommended by the Healthcare Infection Control 
Practices Advisory Committee (HICPAC) of the Centers for Disease Control and Prevention (CDC), by the Infectious Diseases Society of America (IDSA), and by the American Society of Blood and Marrow Transplantation (ASBMT) $[7,8]$.

Hannover Medical School is a tertiary university hospital and each year several hundreds of patients at high risk for water-borne nosocomial infections are cared for in our facility. Eradication of Legionella from our water system is a problematic issue. Copper-silver ionization [9] and hyperchlorination [10] may be possible methods for the reduction of Legionella, but both of these approaches are hardly options in our facility due to the German drinking water regulation law [11]. Superheat and consecutive flushing of the complete plumbing systems at temperatures $>73^{\circ} \mathrm{C}$ [12] demands enormous logistic effort to reduce the risk of scalding on the user's side. Further disadvantages of superheat-and-flush are the cost for energy and possible damage to the plumbing system due to high temperatures. As for ozone treatment [13] and UV radiation [14], long-term success has rarely been reported with superheat-and-flush.

If eradication of Legionella cannot be accomplished, exposition prophylaxis (avoiding contact) may serve as an alternative. Purchase of sterile water [15] for high risk patient care is a quite expensive option and becomes inconvenient for treatment of longer time periods. Therefore we chose the option of point-of-use water filtration $[16,17]$. Water filters, too, are an expensive infection control measure, but prolonged usage intervals before the filters are changed may reduce the costs noticeably. Retrograde bacterial contamination is a well-known problem in the use of tap water filters and limits their usage interval [18]. To extend the usage time of such filters one manufacturer has developed a silver layer on the filtration membrane to diminish biofilm growth.

This article provides data on the quality of water samples after different usage intervals of a newly-developed generation of terminal tap water filters.

\section{Methods}

We decided to conduct surveillance of water samples in an intermediate care unit of the thoracic surgery department. Medical staff and the cleaning personnel on this ward are used in the general handling of tap water filters. After determination of the baseline quality of water, designated water outlets for patient care on this unit were provided with either a modified terminal water filter with a pore size of $0.2 \mu \mathrm{m}$ (Germlyser, Aqua-Free Membrane Technology GmbH, Hamburg, Germany) or with the previous model of this water filter [19] for comparison. In contrast to the preceding model, this new water filter type is sup- plied with a silver layer on the filtration membrane. This silver layer is supposed to diminish growth of bacterial biofilm $[20,21]$. Although intended primarily for re-use after thermal disinfection [22], we only tested the water filters (old and new generation) for their performance in "first use" in this survey without consecutive reprocessing.

First, water samples were drawn from 15 water taps before installation of filters to determine the burden of pathogens in the plumbing system (baseline value). Then these 15 faucets were provided with terminal filters; 5 taps with the older product and 10 taps with the newly-modified device. Testing of filters was randomized and blinded since both generations of filters were indistinguishable in appearance. Neither the staff on the ward nor were the laboratory investigators or the physicians in the infection control department that conducted the study were aware of the type of filter. After providing the taps with filters, we examined water samples after 1,2,3, and 4 weeks of filter usage. Because the entire experiment was performed 4 times we repeatedly used all 15 water taps throughout the study as described above ending up in 60 samples of unfiltered water. In addition, 20 filtered water samples (old product) and 40 filtered water samples (new product) were tested after 1, 2, 3, and 4 weeks of use each (corresponding to 4 cycles with 5 and 10 samples respectively).

All water samples contained mixed (hot and cold) splash water (immediately collected when opening the water tap and starting the water flow) as we believe it is usually used for patient care in a sample volume of $500 \mathrm{~mL}$. We did not perform heating of the water taps for decontamination before taking the sample as recommended in drinking water regulations, but rather adjusted our procedure to the suggestions for water surveillance in hospitals according to Pitten et al. [23].

Laboratory testing of water samples was performed on Legionella selective medium (GVPC agar, Oxoid, Wesel, Germany) at $36^{\circ} \mathrm{C}$ for 7 days as performed in previous studies and described elsewhere [19]. Total bacterial count and identification of specifically relevant pathogens such as coli-like bacteria (MacConkey agar, Oxoid), Pseudomonas aeruginosa (Cetrimid agar, Oxoid), or enterococci (Slanetz-Bartley agar, Oxoid) were also performed according to the German drinking water regulations at $22^{\circ} \mathrm{C}$ for 72 hours and at $36^{\circ} \mathrm{C}$ for 48 hours respectively [24]. Filtration technique was used to culture $P$. aeruginosa. Pourplating technique was used to culture other bacteria for the total bacterial count. The total bacterial count was then performed quantitatively by visual examination. Chemical analysis of water samples (e.g. for heavy metal concentration of for the amount of residual disinfectants) was not performed in our study. We decided to concen- 
trate on microbiological findings first before testing to what extent silver ions dissolve in the water.

Statistical analysis was performed applying Fisher's exact test $(\mathrm{p}<0.05)$ using SPSS $^{\circledast}$ software. An approval of the local ethics committee for this trial was not required because the use of tap water filters is limited to intensive care units and the haematological department in our facility. Thus no other filter systems got replaced during our investigation when testing this new filter device.

\section{Results}

\section{Sample size}

A total of 299 water samples were analyzed during this study. At one water tap, on which a new filter was in place, we did not draw a sample after 4 weeks of use because leakage of the adapter of this particular filter was observed. Laboratory contamination of another water sample drawn from a new filter after 3 weeks of usage occurred at incubation at $22^{\circ} \mathrm{C}$. All other samples were processed as described. Table 1 shows the corresponding laboratory test results and statistical analyses.

\section{Legionella}

29 of 60 unfiltered water samples (48.3\%) were Legionella spp. positive. L. pneumophila serogroup 1 was detected in 12 samples and Legionella of other serogroups ( 2 through 14) were detected in 15 samples. In 2 samples L. pneumophila of serogroup 1 and also of other serogroups were identified. In contrast, filtered water samples did not show growth of Legionella spp. except one single sample that contained 4 CFU per mL of L. pneumophila serogroup
1. No significant differences between different kinds of filters were observed (Table 1).

\section{Other relevant pathogens}

E. coli or coli-like bacteria were not found in any sample. Growth of $P$. aeruginosa was observed in 3 unfiltered water samples ( 1 - 10 CFU per $\mathrm{mL}$ ). In addition, 2 unfiltered water samples were positive for Enterococcus spp. All filtered water samples were negative for any of these potential relevant pathogens.

\section{Total bacterial count}

As shown in Table 1, water samples from both kinds of filters, old and new, showed increased proportion of samples that had $>100 \mathrm{CFU} / \mathrm{mL}$ over time. However, no water sample from the new generation filter system exceeded the concentration of $100 \mathrm{CFU}$ per $\mathrm{mL}$ after 1 week of use at either incubation temperature, compared to $15 \%$ (at $22^{\circ} \mathrm{C} ; \mathrm{p}=0.033$ ) and $10 \%$ (at $36^{\circ} \mathrm{C} ; \mathrm{p}=0.107$ ) of water samples from the older filter device. After 2 weeks of use, still, there was a tendency that fewer samples were contaminated using the new filter (25\%) compared with samples from the preceding model $(45 \%)$ at $22^{\circ} \mathrm{C}(\mathrm{p}=$ $0.146)$, but at incubation temperature of $36^{\circ} \mathrm{C}$ the level of contamination was equal $(20 \%$ each; $\mathrm{p}=1.000)$. No significant differences in the total bacterial count were noticed between the filter systems after a usage interval of 3 or 4 weeks at either incubation temperature.

\section{Discussion}

For all medical departments that take care of highly immunocompromised patients, it is obligatory that effec-

Table I: Growth of Legionella spp. and total bacterial count (p-value compares results of water samples from old filters to results from new filters)

\begin{tabular}{|c|c|c|c|c|c|c|c|c|c|c|}
\hline & & \multicolumn{3}{|c|}{$\begin{array}{l}\text { number of Legionella positive } \\
\text { samples }\end{array}$} & \multicolumn{3}{|c|}{$\begin{array}{c}\text { number of samples }>100 \mathrm{CFU} \text { per } \mathrm{mL} \text { in } \\
\text { total bacterial count at } 22^{\circ} \mathrm{C}\end{array}$} & \multicolumn{3}{|c|}{$\begin{array}{c}\text { number of samples }>100 \mathrm{CFU} \text { per } \mathrm{mL} \text { in } \\
\text { total bacterial count at } 36^{\circ} \mathrm{C}\end{array}$} \\
\hline \multirow{2}{*}{$\begin{array}{c}\text { unfiltered } \\
\text { water }(n=60)\end{array}$} & & & 9 (48.3\%) & & & $18(30.0 \%)$ & & & 33 (55.0\%) & \\
\hline & & $\begin{array}{l}\text { old filter } \\
(\mathrm{n}=20)\end{array}$ & $\begin{array}{l}\text { new filter } \\
(n=40)\end{array}$ & $\mathrm{P}$-value & $\begin{array}{l}\text { old filter } \\
(\mathrm{n}=20)\end{array}$ & $\begin{array}{l}\text { new filter } \\
(\mathrm{n}=40)\end{array}$ & $\mathrm{p}$-value & $\begin{array}{l}\text { old filter } \\
(n=20)\end{array}$ & $\begin{array}{l}\text { new filter } \\
(\mathrm{n}=40)\end{array}$ & $\mathrm{p}$-value \\
\hline \multirow{4}{*}{$\begin{array}{l}\text { filtered water } \\
\text { at different } \\
\text { usage intervals }\end{array}$} & 7 days & $0(0.0 \%)$ & I (2.5\%) & 1.000 & $3(15.0 \%)$ & $0(0.0 \%)$ & 0.033 & $2(10.0 \%)$ & $0(0.0 \%)$ & 0.107 \\
\hline & 14 days & $0(0.0 \%)$ & $0(0.0 \%)$ & 1.000 & $9(45.0 \%)$ & $10(25.0 \%)$ & 0.146 & $4(20.0 \%)$ & $8(20.0 \%)$ & 1.000 \\
\hline & 21 days & $0(0.0 \%)$ & $0(0.0 \%)$ & 1.000 & $10(50.0 \%)$ & $\begin{array}{c}18 \\
(46.2 \%)^{* *}\end{array}$ & 0.787 & 9 (45.0\%) & $20(50.0 \%)$ & 0.788 \\
\hline & 28 days & $0(0.0 \%)$ & $0(0.0 \%)^{*}$ & 1.000 & $9(45.0 \%)$ & 25 (64.1\%)* & 0.177 & 14 (70.0\%) & 27 (69.2\%)* & 1.000 \\
\hline
\end{tabular}

\footnotetext{
* Only 39 samples were tested due to leakage of the adaptor between one filter and its water tap.

** Only 39 samples were tested due to laboratory contamination during processing of one sample.
} 
tive infection control measures are implemented to prevent nosocomial Legionellosis. This may be done by attempting to eradicate pathogens from the water system or by exposition prophylaxis (avoiding contact to pathogens) as described. Because they represent a secure and convenient method to achieve Legionella-free water, we agree that point-of-use filtration by terminal tap water filters in high risk areas are a practical alternative of an infection control strategy to reduce the risk of nosocomial infection. In the data presented in this study, both types of filters eliminated with a single exception Legionella and other relevant water-borne pathogens effectively.

Unlike a recently published study testing this device [22], in our experiments the silver-layer inserted in the newlymodified filter led to a significant decrease of the total bacterial count after the first week of use only. This is most probably due to retrograde contamination during use. As noticed in earlier investigations on terminal tap water filters $[18,19,25,26]$, retrograde contamination is a critical issue over time - even if staff on the ward is used to handling of these devices. Retrograde contamination of the filtration membrane may occur by either splash water from the water basin during use or by direct contact with contaminated hands and dirty cloths from cleaning staff. Therefore regular education of personnel (especially those who are cleaning the washing basins) and detailed instructions to patients are necessary to reduce the risk of unintended retrograde bacterial contamination. Alcoholbased surface disinfection as a routine measure and in the case of visible contamination may further reduce the risk of biofilm growth as recommended by others [22].

One limitation of our study is that we cannot rule out that retrograde contamination has occurred. As a consequence of the above-mentioned study by Daeschlein et al. [22], in which this type of point-of-use filter was examined, a usage interval of 4 weeks in high risk areas and 8 weeks in moderate infectious areas was recommended by the manufacturer. In their study, the water filters were automatically reprocessed in a washer/disinfector and dried at $115^{\circ} \mathrm{C}$ with sterile air. The total bacterial count remained remarkably low $\left(<40 \mathrm{CFU}\right.$ per $\mathrm{mL}$ at $22^{\circ} \mathrm{C}$ as well as $36^{\circ} \mathrm{C}$ ) over 8 weeks of use. Nevertheless, the exact clinical impact of other so-called "non-pathogenic" bacteria in the water samples in the subsequent risk of infection for highly immunocompromised patients is yet unknown. Another limitation of our study is that we only checked for the performance of the water filters in the first week of use but not after reprocessing. This practice was chosen because we primarily wanted to assess the baseline quality of a new product that was still within the development process at that time.
Oyanedel-Craver et al. used colloidal-silver-impregnated ceramic filters for point-of-use water treatment and determined silver concentrations in the effluent water; the values were initially $>0.1 \mathrm{mg} / \mathrm{L}$ but dropped below this value after continuous operation [27]. Others confirmed that this concentration is effective in killing pathogens [28] and the WHO considers this concentration being safe for human health [29]. Unfortunately, as another limitation of the present study, neither we nor Daeschlein et al. [22] measured the concentration of silver ions in the water samples in the Germlyser filter device.

\section{Conclusion}

We are well aware of the presence of Legionella spp. in our hospital water supply system and point-of-use filtration has been the method of choice for high risk patient care in our facility for years. Since the beginning of active surveillance in 2000, to our knowledge, no cases of nosocomial Legionellosis have occurred in our hospital. That is, why we and others [30] propose using tap water filter primary for the prevention of nosocomial Legionellosis for high risk patient groups. The use of anti-bacterial components in the manufacturing process of water filters might be helpful for the prevention of biofilm growth and the extension of the usage interval of such devices.

\section{List of abbreviations}

CFU: colony forming unit; HICPAC: Healthcare Infection Control Practices Advisory Committee; CDC:Centers for Disease Control and Prevention; IDSA: Infectious Diseases Society of America; ASBMT: American Society of Blood and Marrow Transplantation;

\section{Competing interests}

Funding of $€ 10.000$ was received from Aqua-Free Membrane Technology GmbH, Hamburg, Germany, to conduct this study.

\section{Authors' contributions}

Water sampling and microbiological evaluation was carried out by RPV, JB, and PG. DS performed statistical analysis of the results. The manuscript was written by RPV and PG. All authors read and approved the final manuscript.

\section{Acknowledgements}

The authors would like to thank the staff from the infection control laboratory for the examination of the water samples.

\section{References}

I. Ditommaso S, Biasin C, Giacomuzzi M, Zotti CM, Arione R, Guglielmi E, Barbaro S, Di Leo A, Serra R, Marchiaro G, Ruggenini MA: Colonization of a water system by Legionella organisms and nosocomial legionellosis: a 5-year report from a large Italian hospital. Infect Control Hosp Epidemiol 2006, 27:532-535.

2. Fujimura S, Oka T, Tooi O, Meguro M, Chiba M, Kawamura M, Maki $F$, Takeda H, Watanabe A: Detection of Legionella pneumophila serogroup 7 strain from bathwater samples in a Japanese hospital. J Infect Chemother 2006, I 2:105-108. 
3. Schindel C, Siepmann U, Han S, Ullmann AJ, Mayer E, Fischer T, Maeurer M: Persistent Legionella infection in a patient after bone marrow transplantation. J Clin Microbiol 2000, 38:4294-4295.

4. Korman TM, Fuller A, Ibrahim J, Kaye D, Bergin P: Fatal Legionella longbeachae infection following heart transplantation. Eur J Clin Microbiol Infect Dis 1998, 17:53-55.

5. Humphreys H, Marshall RJ, Mackay I, Caul EO: Pneumonia due to Legionella bozemanii and Chlamydia psittaci/TWAR following renal transplantation. J Infect 1992, 25:67-7I.

6. Mathys W, Deng MC, Meyer J, Junge-Mathys E: Fatal nosocomia Legionnaires' disease after heart transplantation: clinical course, epidemiology and prevention strategies for the highly immunocompromized host. J Hosp Infect 1999, 43:242-246.

7. Tablan OC, Anderson LJ, Besser R, Bridges C, Hajieh R: Guidelines for preventing health-care-associated pneumonia, 2003: recommendations of CDC and the Healthcare Infection Control Practices Advisory Committee. MMWR Recomm Rep 2004, 53:1-36.

8. CDC, IDSA, ASBMT: Guidelines for preventing opportunistic infections among hematopoietic stem cell transplant recipients. Recommendations of CDC, the Infectious Disease Society of America, and the American Society of Blood and Marrow Transplantation. Cytotherapy 200I, 3:4I-54.

9. Stout JE, Yu VL: Experiences of the first 16 hospitals using copper-silver ionization for Legionella control: implications for the evaluation of other disinfection modalities. Infect Control Hosp Epidemiol 2003, 24:563-568.

10. Helms CM, Massanari RM, Wenzel RP, Pfaller MA, Moyer NP, Hall N: Legionnaires' disease associated with a hospital water system. A five-year progress report on continuous hyperchlorination. JAMA 1988, 259:2423-2427.

II. Verordnung zur Novellierung der Trinkwasserverordnung vom 2I. Mai 200I (German drinking water regulations revised on May 2 I st 200I). BGBI 200I, I:959-980.

12. Chen YS, Liu YC, Lee SS, Tsai HC, Wann SR, Kao CH, Chang CL, Huang WK, Huang TS, Chao HL, Li CH, Ke CM, Lin YS: Abbreviated duration of superheat-and-flush and disinfection of taps for Legionella disinfection: lessons learned from failure. Am J Infect Control 2005, 33:606-6I0.

13. Edelstein PH, Whittaker RE, Kreiling RL, Howell CL: Efficacy of ozone in eradication of Legionella pneumophila from hospital plumbing fixtures. Appl Environ Microbiol 1982, 44:1330-1333.

14. Knudson GB: Photoreactivation of UV-irradiated Legionella pneumophila and other Legionella species. Appl Environ Microbiol 1985, 49:975-980.

15. Marrie TJ, Haldane D, MacDonald S, Clarke K, Fanning C, Fort-Jost S, Bezanson G, Joly J: Control of endemic nosocomial legionnaires' disease by using sterile potable water for high risk patients. Epidemiol Infect 199|, 107:59|-605.

16. Ortolano GA, McAlister MB, Angelbeck JA, Schaffer J, Russell RL, Maynard E, Wenz B: Hospital water point-of-use filtration: a complementary strategy to reduce the risk of nosocomia infection. Am J Infect Control 2005, 33(5 SuppI I):SI-I9.

17. Exner M, Kramer A, Lajoie L, Gebel J, Engelhart S, Hartemann P: Prevention and control of health care-associated waterborne infections in health care facilities. Am J Infect Control 2005, 33(5 Suppl I):S26-S40

18. Sheffer PJ, Stout JE, Wagener MM, Muder RR: Efficacy of new point-of-use water filter for preventing exposure to Legionella and waterborne bacteria. Am J Infect Control 2005 , 33(5 Suppl I):S20-S25.

19. Vonberg RP, Rotermund-Rauchenberger D, Gastmeier P: Reusable terminal tap water filters for nosocomial legionellosis prevention. Ann Hematol 2005, 84:403-405.

20. Hambidge A: Reviewing efficacy of alternative water treatment techniques. Health Estate 200I, 55:23-25.

21. Molloy SL, Ives R, Hoyt A, Taylor R, Rose JB: The use of copper and silver in carbon point-of-use filters for the suppression of Legionella throughput in domestic water systems. J Appl Microbiol 2008, 104:998-1007.

22. Daeschlein G, Kruger WH, Selepko C, Rochow M, Dolken G, Kramer A: Hygienic safety of reusable tap water filters (Germlyser) with an operating time of $\mathbf{4}$ or $\mathbf{8}$ weeks in a haematological oncology transplantation unit. BMC Infect Dis 2007, 7:45.
23. Pitten F, Rudolph P, Kramer A: Mikrobiologische Qualität von Trinkwasser in Risikobereichen (Microbiological quality of drinking water in high risk areas). Bundesgesundheitsbl 200I, 44:155-158.

24. Nachweis von Legionellen in Trinkwasser und Badebeckenwasser (Detection of Legionella in drinking water and bathing water). Bundesgesundheitsbl 2000, 43:91I-9/5.

25. Vonberg RP, Eckmanns T, Bruderek J, Ruden H, Gastmeier P: Use of terminal tap water filter systems for prevention of nosocomial legionellosis. J Hosp Infect 2005, 60:159-162.

26. Wendt C, Weist K, Dietz E, Schlattmann P, Ruden H: Feldversuch zur Gewinnung legionellenfreien Wassers aus Duschen und Waschbecken einer Transplantationsstation durch ein Wasserfiltersystem (Field study to obtain Legionella-free water from showers and sinks of a transplantation unit by a system of water filters). Zentralbl Hyg Umweltmed 1995, 196:515-531.

27. Oyanedel-Craver VA, Smith JA: Sustainable colloidal-silverimpregnated ceramic filter for point-of-use water treatment. Environ Sci Technol 2008, 42:927-933.

28. Silvestry-Rodriguez N, Bright KR, Uhlmann DR, Slack DC, Gerba CP: Inactivation of Pseudomonas aeruginosa and Aeromonas hydrophila by silver in tap water. I Environ Sci Health A Tox Hazard Subst Environ Eng 2007, 42: 1579-I 584.

29. Silver. In Guidelines for Drinking Water Quality 3rd edition. The World Health Organization; 2006:335-337.

30. Salvatorelli G, Medici S, Finzi G, De Lorenzi S, Quarti C: Effectiveness of installing an antibacterial filter at water taps to prevent Legionella infections. J Hosp Infect 2005, 6 I:270-27I.

\section{Pre-publication history}

The pre-publication history for this paper can be accessed here:

\section{http://www.biomedcentral.com/1471-2334/8/133/pre}

pub
Publish with Biomed Central and every scientist can read your work free of charge

"BioMed Central will be the most significant development for disseminating the results of biomedical research in our lifetime. "

Sir Paul Nurse, Cancer Research UK

Your research papers will be:

- available free of charge to the entire biomedical community

- peer reviewed and published immediately upon acceptance

- cited in PubMed and archived on PubMed Central

- yours - you keep the copyright
BioMedcentral 